\title{
COMMENTS
}

\section{Rethinking What Agriculture Could Use: A Proposed Heightened Utility Standard for Genetically Modified Food Patents*}

\section{INTRODUCTION}

The era of biotechnology is upon us. ${ }^{1}$ For ages, human beings have manipulated natural phenomena to enhance their ability to feed themselves, ${ }^{2}$ but the recent development of recombinant DNA technology has revolutionized this process. Now, through genetic modification $(\mathrm{GM})^{3}$, researchers can cause one organism to express genes from an altogether different organism. ${ }^{4}$ The resulting genetically modified organisms (GMOs) are already commonplace in American crop fields ${ }^{5}$ and pave the way for incredibly exciting advancements in agriculture, ranging from more productive fields that require less pesticides to crops that produce biodegradable plastics or cheap pharmaceuticals. ${ }^{6}$ Alongside these positive developments, however, are a host of concerns focused primarily on the potential impact of this new technology on the environment and human health. ${ }^{7}$ Although the

Zachary Lerner. I would like to thank Nancy Marshall, Professor Andrew Torrance, Brian Dietz, Professor Keith Meyer, and Catherine Foulston for the various ways in which they helped me with this Comment.

1. See Rebecca M. Bratspies, Consuming (F)ears of Corn: Public Health and Biopharming, 30 AM. J.L. \& MED. 371,371 (2004) ("We have entered the biotech century.").

2. John S. Applegate, The Prometheus Principle: Using the Precautionary Principle to Harmonize the Regulation of Genetically Modified Organisms, 9 IND. J. GLOBAL LEGAL STUD. 207, $207(2001)$.

3. The acronym "GM" appears in this Comment to signify the term "genetic modification" as well as the modifier "genetically modified." Organisms that are genetically modified are also commonly called "genetically engineered," "transgenic," and "bioengineered." Gregory N. Mandel, Gaps, Inexperience, Inconsistencies, and Overlaps: Crisis in the Regulation of Genetically Modified Plants and Animals, 45 WM. \& MARY L. REV. 2167,2175 (2004).

4. Bratspies, supra note 1 , at 377 .

5. Mandel, supra note 3, at 2177.

6. Id. at 2180-87.

7. Id. at 2190-99. 
available scientific evidence so far has suggested that GM crops are safe, ${ }^{8}$ the debate about the wisdom of their widespread use rages on. ${ }^{9}$

The purpose of this Comment is not to promote one side of the debate over the other. It takes for granted that fundamental positions of both camps are correct: ${ }^{10} \mathrm{GM}$ agriculture is the wave of the future, and this future is uncertain. It also assumes that there are some fundamental goals upon which everyone can agree. ${ }^{11}$ The question becomes how the law can promote these goals. The current regulatory scheme covering GMOs has been criticized as inefficient, incomplete, and inadequate to adapt to advancements in agricultural biotechnology while addressing its risks. ${ }^{12}$ This Comment takes a different approach and asks whether the patent law, through its requirement that inventions be "useful" to deserve patent protection, can be an independent legal tool for advancing important public policy regarding the next generation of agriculture. ${ }^{13}$

Part II of this Comment illustrates modern American agriculture through a representative examination of the highly prevalent practice of growing corn. It goes on to consider the history and potential of GM technology. Part III then reviews the incentive system that patent law creates and the basic requirements for obtaining a patent. In particular, it explores the patent law's insistence that inventions be "useful" to receive a patent, which is known as the utility requirement. Part IV proposes a framework for the creation of a new heightened utility standard designed to address the unique challenges of GM agriculture and considers the limitations of such a proposal.

8. See generally Philip J. Dale et al., Potential for the Environmental Impact of Transgenic Crops, 20 NATURE BIOTECH. 567 (2002) (reporting scientific evidence about numerous environmental concerns of GM crops); see also Mandel, supra note 3, at 2190 (reporting that "there is no confirmed case of human disease or illness caused by genetically modified food").

9. See generally Neil D. Hamilton, Forced Feeding: New Legal Issues in the Biotechnology Policy Debate, 17 WASH. U. J.L. \& POL'y 37 (2005) (providing a "concise update of many of the significant legal and policy issues shaping American law as relates to agricultural biotechnology").

10. Cf. Mandel, supra note 3, at 2171 ("A review of the data and information available concerning genetically modified products demonstrates that both camps are right, and wrong.").

11. These goals are embodied in the Criteria set forth in this Comment. See infra Part IV.B.

12. Mandel, supra note 3, at 2167.

13. It should be noted from the outset that this Comment's proposal need not apply exclusively to GMOs in agriculture, or even to agriculture inventions in general. For the sake of simplified discussion, and because of the heated debate surrounding the use of GMOs in agriculture, this Comment focuses on inventions that relate to GM technology in crops. 


\section{AMERICAN AGRICULTURE AND THE RISE OF GM TECHNOLOGY}

\section{A. A Case Study of American Agriculture: Corn}

The first section of Michael Pollan's 2006 book The Omnivore's Dilemma paints a detailed picture of the United States' intimate relationship with $\operatorname{corn}^{14}$ and provides a representative glimpse into the current state of American agriculture. As Pollan puts it, "[ $t]$ he great edifice of variety and choice that is an American supermarket turns out to rest on a remarkably narrow biological foundation comprised of a tiny group of plants that is dominated by a single species: Zea mays, the giant tropical grass most Americans know as corn." 15 Corn is an obvious ingredient in some products, such as corn on the cob, tortillas, muffins, and chips, ${ }^{16}$ but many other food and nonfood items derive from corn. ${ }^{17}$ Corn feeds cattle that become steak or produce dairy items, chickens that lay eggs, and other animals we eat such as pigs, sheep, turkeys, catfish, and tilapia. ${ }^{18}$ "Wet mills," which are a type of corn processing plant, break corn down into its constituent parts-embryo, endosperm, and fiber-and use them to make "innumerable" derivative products, such as corn oil, cornstarch, citric and lactic acid, glucose, maltodextrine, ethanol, xanthum gum, monosodium glutamate (MSG), and highfructose corn syrup. ${ }^{19}$ Thus, products derived from corn serve as the building blocks that compose processed foods, such as chicken nuggets, whose corn-dependent ingredients include not only the chicken itself, but also corn flour, corn oil, leavenings, lecithin, mono-, di-, and triglycerides, and golden coloring. ${ }^{20}$ Corn even plays a role in the production of many nonfood items, such as toothpaste, cosmetics, diapers, trash bags, batteries, and the vegetable wax that gives some supermarket produce its sheen. ${ }^{21}$

Corn is so prevalent in American agriculture at least in part because it is among the cheapest ways to transfer energy from an acre of farmland to human bodies through such forms as animal fat, sugar, or

14. MiChaEl Pollan, The OMNIVORE'S Dilemma 15-119(2006)

15. Id. at 18 .

16. See id. at 85 (noting that "most of the corn we eat as corn-whether on the cob, flaked, or baked into muffins or tortillas or chips-comes from varieties other than [the lower quality variety used for such purposes as animal feed and processing]").

17. Id. at 18-19.

18. Id. at 18 .

19. Id. at $85-88$.

20. Id at 18 .

21. Id. at 19 . 
starch. ${ }^{22}$ During photosynthesis, corn creates compounds with four carbon atoms. ${ }^{23}$ This trait places it among a small group of "C-4" plants that can manufacture more organic matter and calories from the same amount of sunlight, water, and basic elements than most other plants. ${ }^{24}$ Additionally, corn's method of reproduction lends itself well to human intervention: through hybridization, human beings "arrange [corn's] marriages" and create breeds with particular traits, including adaptation to a range of climates and stronger stalks and roots that can withstand mechanical harvesting. ${ }^{25}$ First generation (F-1) hybrid plants are genetically identical to each other; no single plant has a competitive advantage, so resources are shared equally, resulting in a "crowded metropolis" of corn. ${ }^{26}$ Whereas in 1920 the average corn yield per acre was twenty bushels, today F-1 hybrids can yield 180 bushels per acre, which corresponds to about 10,000 pounds of food. ${ }^{27}$ Many corn farmers now use the latest innovation in agricultural biotechnology, GM seeds, which can increase crop yields even more. ${ }^{28}$

The development of such a high-yielding and useful crop seems like a positive advancement in agriculture, but various costs accompany the corn monoculture. ${ }^{29}$ For example, the monoculture enhances the conversion of natural habitats into manmade farmland. ${ }^{30}$ Moreover, monoculture has diminished agricultural diversity and, unlike alternative practices like crop rotation that help maintain biodiversity and ecological balance, monoculture plays a role in the extinction of wild species. ${ }^{31}$ The trend towards monoculture also raises concerns that are more social or cultural in nature, as illustrated by farms in Iowa, where in the early twentieth century farmers raised cattle, chickens, hogs, apples, hay, oats,

22. Id. at 108 .

23. Id. at 21 .

24. Id. at 21-22. Because of this "C-4 trick," corn plants end up with relatively more of the isotope carbon 13; the proportion of carbon 13 in a person's flesh indicates how much corn is in his or her diet. $\quad$ Id. at 22 . According to a Berkeley biologist who has researched this phenomenon, "North Americans look like com chips with legs." Id. at 23

25. Id. at 30,37 .

26. Id. at 31,37 .

27. Id. at $36-37$.

28. See id. at 36 ("As [one farmer] sees it, GMO seed is just the latest chapter in an old story: Farmers eager to increase their yields adopt the latest innovation ....").

29. Monoculture is the result of "intensive and continual farming of one type of crop or one variety of seed on [one] plot of land." Mohsen Al Attar Ahmed, Monocultures of the Law: Legal Sameness in the Restructuring of Global Agriculture, 11 DRAKE J. AGRIC. L. 139, 143 (2006).

30. See, e.g., POLLAN, supra note 14, at 38 ("A mere 2 percent of [Iowa's] land remains what it used to be (tall-grass prairie), every square foot of the rest having been completely remade by man.").

31. Ahmed, supra note 29 , at $146-47$. 
potatoes, cherries, wheat, plums, grapes, and pears in addition to corn. ${ }^{32}$ By the $1980 \mathrm{~s}$, corn largely pushed out other forms of agriculture as well as many farmers: "One man can handle a lot more acreage by himself when it's planted in monoculture, and without animals to care for he can take the weekend off ...."33

The use of nitrate fertilizers necessary to obtain high crop yields provides another set of environmental costs associated with the growing of corn. ${ }^{34}$ American farmers apply more fertilizer to corn than any other crop. $^{35}$ The production of artificial nitrate fertilizer requires heat and pressure, usually supplied by fossil fuels; fertilizer for one acre of corn requires about fifty gallons of oil. ${ }^{36}$ Also, run-off from nitrate fertilizer can pollute human drinking water $^{37}$ and natural ecosystems. ${ }^{38}$ A wild growth of algae as big as New Jersey resulting from run-off from the Mississippi River has appeared in the Gulf of Mexico-a "dead zone" for fish."

Because of corn's biological characteristics, the "perverse economics of agriculture," which do not follow the usual rules of supply and demand, ${ }^{40}$ and a history of governmental farm subsidies, American farms grow a surplus of corn-a "plague of cheap corn."41 One way to use these cheap calories is to feed them to cows that can convert them into protein. ${ }^{42}$ But cows have evolved to be grass eaters; ${ }^{43}$ feeding them corn

32. POLLAN, supra note 14 , at 38 .

33. Id. at $39-40$

34. See id. at 41-47 (describing the history and environmental implications of synthetic nitrate fertilizer used to grow com).

35. See id. at 41 ("Hybrid com is the greediest of plants, consuming more fertilizer than any other crop."); see also NAT'L AGRIC. STATISTICS SERV., U.S. DEP'T OF AGRIC., AGRICULTURAL CHEMICAL USAGE: 2005 FIELD CROPS SUMMARY 8, 38, 56 (2006) (reporting 2005 use of fertilizer on major U.S. crops by state).

36. POLLAN, supra note 14 , at $44-45$.

37. Id. at 46-47 (explaining how the city of Des Moines occasionally issues "blue baby alerts" to warn parents that nitrogen levels in tap water are dangerously high for consumption by children).

38. See id. at 47 ("The flood of synthetic nitrogen has fertilized not just the farm fields but the forests and the oceans too ....").

39. Id.

40. Id. at 48,54 . “"The economics of a family farm are very different than a firm's: When prices fall, the firm can lay off people, idle factories, and make fewer widgets. Eventually the market finds a new balance between supply and demand. But the demand for food isn't elastic; people don't eat more just because food is cheap. And laying off farmers doesn't help to reduce supply. You can fire me, but you can't fire my land, because some other farmer who needs more cash flow or thinks he's more efficient that I am will come in and farm it. Even if I go out of business this land will keep producing corn." Id. at 54 (quoting George Naylor, an Iowa farmer).

41. Id. at $47-54$.

42. Id. at 71,74 .

43. Id. at 70. Although corn itself is a "grass," see supra note 15 and accompanying text, the grasses that cows have evolved to eat are, for example, those native to the Great Plains, such as 
acidifies their digestive systems, necessitating the widespread use of antibiotics like Rumensin and Tylosin and causing the development of acid-resistant $E$. coli strains that are particularly threatening to humans. ${ }^{44}$

Another method of utilizing the corn surplus is to convert it into processed foods via industrial processing plants. ${ }^{45}$ This is an attractive option to the food industry who can increase profits at a faster rate than the finitely sized stomachs of consumers would otherwise allow by creating value-added complex food systems from cheap raw materials. ${ }^{46}$ Today processors can do hundreds of things with corn, the "cleverest" of which is to refine it into high-fructose corn syrup. ${ }^{47}$ This cheap sweetener "has insinuated itself into every corner of the pantry: not just into our soft drinks and snack foods, . . . but into the ketchup and mustard, the breads and cereals, the relishes and crackers, the hot dogs and hams." 48 High-fructose corn syrup thus "gets [people] to really chomp through the corn surplus." $" 49$ While most Americans do not consider themselves big corn eaters, the average American consumes one ton of corn every year. ${ }^{50}$ This trend may play a role in a myriad of health issues: obesity is now officially an epidemic, costing the health care system some ninety-billion dollars per year; one out of every three children born in 2000 will develop Type II diabetes (no longer called "adult-onset" diabetes); and today's children may be the first generation to have a shorter life expectancy than their parents. ${ }^{51}$

The model of corn production that Pollan illuminates is a prototypical example of "industrial agriculture." 52 It evokes a handful of

western wheatgrass, little bluestem, green needlegrass, and buffalo grass. See id. at 69 (listing grasses that a typical cow eats before journeying to the feedlot).

44. Id. at 78, 81-82. E. Coli is a "bacterium whose natural habitat is the feces of hoofed animals." Robin Finn, A Public Health Doctor Caught Up in an E. Coli Mystery, N.Y. TIMES, Dec. 15,2006 , at B4. Although human infections have traditionally been associated with hamburger meat, "it is developing a habit of sneaking into the human food chain via vegetables," id, as evidenced by the California-spinach-related outbreak in September 2006 that killed at least three people and sickened more than two hundred and the subsequent outbreak initially linked to green onions, and later shredded lettuce, at Taco Bell restaurants on the East Coast. Bruce Lambert, Shredded Lettuce Is Now Chief Suspect in E. Coli Outbreak, N.Y. TimEs, Dec. 14, 2006, at B9; Andrew Martin, With Focus Off Onions, E. Coli Hunt Continues, N.Y. TIMES, Dec. 13, 2006, at B1.

45. See POLLAN, supra note 14 , at $85-90$ (describing com processing at "wet mills").

46. Id. at $94-95$.

47. Id. at 103 .

48. Id. at 104 .

49. Id.

50. Id. at 85 .

51. See id. at 101-02 (referencing these health problems and suggesting that one reason for them is that "[w]hen food is abundant and cheap, people will eat more of it and get fat").

52. See, e.g., Ahmed, supra note 29, at 143-44 (describing industrial agriculture); see also POLLAN, supra note 14, at 17 (characterizing the topic of his study as "the industrial food chain"). 
environmental, social, and public health related issues whose underlying causes are most likely numerous and complex. ${ }^{53}$ Biotechnology, in a broad sense, is the "use of living organisms to make new products," a definition that includes such old-fashioned techniques as traditional plant breeding or the use of bacteria to convert milk into yogurt. ${ }^{54}$ In this broad sense, biotechnology has played an essential role in the emergence of industrial agriculture: for example, the hybridization of different varieties of corn boosted yields and enabled mechanical harvesting. ${ }^{55} \mathrm{~A}$ narrower definition of biotechnology encompasses newer "artificial" practices, with particular focus on recombinant DNA technology, in contradistinction to older "natural" processes. ${ }^{56}$ Biotechnology, in this narrower sense, has already begun to reshape agriculture. ${ }^{57}$ The next subpart of this Comment describes the next generation of biotechnology: GM technology.

\section{B. GM Technology: The Next Generation in Agriculture}

\section{A Brief History of GMOs and Their Integration into American Agriculture}

For thousands of years, human beings have selectively bred plants to propagate characteristics that serve human needs. ${ }^{58}$ The work of Gregor Mendel and Charles Darwin in the mid-nineteenth century began to elucidate the mechanics of this process, and the actual mechanism, DNA, was discovered by Watson and Crick in $1953 . .^{59}$ In the early $1970 \mathrm{~s}$, Stanley Cohen and Hubert Boyer accomplished the first successful use of recombinant DNA technology when they successfully spliced a gene from one organism and put it in another. ${ }^{60}$ Using this process, scientists

53. See, e.g., POLLAN, supra note 14, at 39 (acknowledging the importance of the tractor in the development of modern corn farming).

54. Frederick H. Degnan, Legal Aspects of FDA 's Regulation of Food Biotechnology, SJ033 A.L.I.-A.B.A. COURSE OF STUDY MATERIALS 131, 133 (2003).

55. See supra notes 22-27 and accompanying text.

56. See Lars Noah, Managing Biotechnology's [R] evolution: Has Guarded Enthusiasm Become Benign Neglect?, 11 VA. J.L. \& TECH., Spring 2006, at 1-6 (explaining various meanings of the term "biotechnology"). As used subsequently in this Comment, "biotechnology" tends to carry the narrower meaning: "applied biological science (as bioengineering or recombinant DNA technology)." WEBSTER'S NEW ENCYCLOPEDIC DICTIONARY 179 (2002); see also Noah, supra, at 2-3 (citing similar definition).

57. See supra note 28 and accompanying text.

58. Applegate, supra note 2.

59. Id. at $207 \&$ nn.2-3.

60. Bratspies, supra note 1 , at 377 . 
can defeat the limits of reproductive incompatibility of different species and cause one species to express the particular traits of an altogether different species. ${ }^{61}$

The United States Food and Drug Administration approved the first GM product for human consumption in 1994, Calgene's Flavr Savr tomato, which had delayed ripening characteristics to prolong shelf life. ${ }^{62}$ Since then, more than fifty GM crops have been commercialized in the United States, where an estimated $70 \%$ of food in grocery stores contains GM ingredients. ${ }^{63} \mathrm{GM}$ seeds became $40 \%$ of the corn, $81 \%$ of the soybeans, and $73 \%$ of the cotton grown in the United States in $2003 .{ }^{64}$ Farmers in the United States planted over 130 million acres with GM crops in 2006, which is an increase of over 11 million acres from 2005, and more than any other country in the world. ${ }^{65}$ The use of GM crops, in the United States and globally, is expected to continue to rise. ${ }^{66}$

Two common GM crops are "Bt" corn and "Roundup Ready" soybeans. ${ }^{67} \mathrm{Bt}$ corn incorporates genetic material from Bacillus thuringiensis $(\mathrm{Bt}),{ }^{68}$ a "naturally occurring ubiquitous soil bacterium that produces a toxin lethal to certain insects." ${ }^{69}$ For decades farmers have sprayed Bt toxin over crops, but such topical application often loses its effectiveness within days. ${ }^{70}$ By inserting the Bt gene into corn, the crop itself continuously produces the Bt toxin in essentially every part of the plant. $^{71}$ Roundup Ready soybeans are genetically modified to tolerate herbicides, which increases crop yield by making weed elimination easier. $^{72}$

61. See id. at 377-78 ("Suddenly researchers could move genes from one species to another, thus overcoming the reproductive limits imposed by sexual incompatibility among species."). For a helpful explanation of the basic scientific procedure behind recombinant DNA technology, see In re O'Farrell, 853 F.2d 894, 895-99 (Fed. Cir. 1988).

62. Degnan, supra note 54, at 137.

63. Mandel, supra note 3, at 2176-77. Fritos corn chips, Coca-Cola, McDonald's french fries, and Nestle's chocolates are some examples of common food items that contain GM ingredients. Id. at 2177 n.20.

64. Id. at 2177 .

65. Clive James, Int'l Serv. for the ACQuistition of Agri-Biotech Applications, Executive Summary to BRIEF 35: GLOBAL STATUS OF COMMERCIALIZED BIOTECH/GM CROPS: 2006, at 5 (2006).

66. Id. at 8 .

67. Holly Beth Frompovicz, Comment, A Growing Controversy: Genetic Engineering in Agriculture, 17 VILL. ENVTL. L.J. 265, 267 (2006).

68. John Charles Kunich, Mother Frankenstein, Doctor Nature, and the Environmental Law of Genetic Engineering, 74 S. CAL. L. REV. 807, 810 \& n.15 (2001).

69. Dale et al., supra note 8 , at 568 .

70. Kunich, supra note 68 , at 810 .

71. Id. at 810-11.

72. Frompovicz, supra note 67 , at 267. 


\section{Commonly Perceived Benefits and Costs of GMOs in Agriculture}

Proponents of GM technology point to an array of potential benefits of the technology, such as reaping higher crop yields more efficiently, reducing irrigation, reducing herbicide and pesticide use, reducing crop loss to pests, improving crop quality, and the targeting of only harmful insects. $^{73}$ Advantages even include the creation of more nutritious crops that can help combat world hunger: for example, Monsanto has produced a GM rice, "golden rice," which contains high levels of beta carotene to prevent vitamin A deficiency-related health problems. ${ }^{74}$ More "dazzling possibilities" include plants that produce biodegradable plastics and polyesters or drugs to treat various human diseases, ${ }^{75}$ or plants that can absorb toxic waste. ${ }^{76}$

On the other hand, critics of genetic modification fear an array of potential dangers associated with the technology. These concerns generally fall into three categories: risks to human health, risks to the environment, and risks to agriculture. ${ }^{77}$ Examples of human healthrelated concerns include the risk that someone who consumes a GM food product suffers an allergic reaction to an otherwise nonexistent protein in the food; the risk that exposure to the high levels of "natural" pesticides like $\mathrm{Bt}$ toxin could have adverse effects on some people, particularly in the long term; and the fear that certain genes from GM crops with antibiotic-resistance characteristics could be transferred to individuals consuming those crops and ultimately reduce the effectiveness of medical antibiotic treatment. ${ }^{78}$ Environmental concerns range from issues related to gene flow, whereby new genetic material from GM crops could move into unintended organisms and create "superweeds" that normal herbicides cannot control; to extinction of wild species resulting from the invasion of nonindigenous GM crops into natural habitats; to threats to insects and other animals that are susceptible to but

73. Id. at $268-69$.

74. Id. at 269 .

75. Bratspies, supra note 1 , at 372 . In March 2007 , a biopharmaceutical company obtained preliminary approval from the U.S. Department of Agriculture to grow, on 3000 acres of farmland in Kansas, GM rice capable of producing human proteins that could be refined to create medicines to fight diarrhea and other illnesses in children. Sam Hananel, USDA Approves Plan to Grow Genetically Modified Rice in Kansas, YAHOO! FIN., March 2, 2007, http://biz.yahoo.com/ap/070302/ rice pharming.html?.v $=2$.

76. Frompovicz, supra note 67 , at 269

77. Matthew Rich, The Debate Over Genetically Modified Crops in the United States. Reassessment of Notions of Harm. Difference, and Choice, 54 CASE W. RES. L. REV. 889, 894 (2004).

78. Id. at 894-95. 
not targeted by GMO-expressed pesticide; to potential increases in herbicide residue in the environment or reduction in biodiversity resulting from greater application of herbicides by farmers who know their crops are herbicide-resistant. ${ }^{79}$ Finally, risks to agriculture include the economic costs to farmers who must keep up with increasing prices in high-tech seeds and may face a smaller foreign market resulting from international restrictions on GM imports. ${ }^{80}$

The fear that GMOs endanger the environment found support in a 1999 study that found that larvae of the monarch butterfly were harmed by eating milkweed dusted with $\mathrm{Bt}$ corn pollen, ${ }^{81}$ and a 2001 report that genetic material from GM corn had found its way into native varieties of Mexican maize. ${ }^{82}$ However, subsequent inquiry called the validity of both of the studies into question. ${ }^{83}$ Since then, the available scientific evidence has not supported the critics' fears regarding human health ${ }^{84}$ or environmental disaster, ${ }^{85}$ and farmers seem willing to plant GM crops despite potential economic challenges. ${ }^{86}$ Nonetheless, the debate over the advisability of GMOs in agriculture continues because of at least one detail that GM opponents can use to justify their position now and for several years to come: the absence of long-term studies on GMO impact. $^{87}$

The combination of the general lack of confirmed negative GM consequences to date and the apparent acquiescence to the technology by American farmers support the conclusion that GM crops will continue to play an important, and likely increasing, role in American agriculture. This point leads us to the crux of this Comment's quandary: how can we ensure that GM technology brings about the benefits that proponents tout rather than simply multiplying the profits of GM seed companies while

79. Mandel, supra note 3, at 2194-98.

80. Rich, supra note 77 , at $898-99$.

81. John E. Losey et al., Transgenic Pollen Harms Monarch Larvae, 399 NATURE 214, 214 (1999).

82. David Quist \& Ignacio H. Chapela, Transgenic DNA Introgressed into Traditional Maize Landraces in Oaxaca, Mexico, 414 NATURE 541-43 (2001).

83. Declan Butler, Alleged Flaws in Gene-Transfer Paper Spark Row Over Genetically Modified Maize, 415 NATURE 948, 948 (2002); John Hodgson, Monarch Bt-Corn Paper Questioned, 17 NATURE BIOTECH. 627, 627 (1999).

84. See, e.g., Mandel, supra note 3, at 2190 ("[1]t is important to note that there is no confirmed case of human disease or illness caused by genetically modified food.").

85. See generally Dale et al., supra note 8 (reporting scientific evidence related to environmental concerns of GM crops).

86. See supra notes 64-66 and accompanying text (noting prevalence and increasing trend of GM crop use in the United States).

87. See, e.g., Rich, supra note 77 , at 895 ("Furthermore, the effects [on human health] of longterm exposure [to GM food] are unknown."). 
continuing, or worse, exacerbating, the arguably dangerous food production model that Michael Pollan's depiction of corn typifies?

\section{Industrial Agriculture: Meet GMOs}

Another set of potential costs and benefits associated with GMOs is their capacity to affect the current industrial agricultural model. GM technology in agriculture may pave the way for the amelioration of the negative aspects of industrial agriculture, or it may open the door to a new episode of industrial agriculture that is even less desirable than the current model. To illustrate this fork in the road, one requires a more precise definition of the negative aspects of industrial agriculture.

For purposes of illustration, three examples of the negative aspects of industrial agriculture derived from Pollan's depiction of corn are helpful. First, the monoculture decreases agricultural diversity, which is undesirable because agricultural diversity promotes genetic variation and ecological balance. ${ }^{88}$ Second, the monoculture requires the constant input of chemical fertilizer. ${ }^{89}$ This is undesirable because chemical fertilizer requires oil consumption and causes environmental damage. ${ }^{90}$ Third, the monoculture is a key element in the creation of a surplus of one type of crop (concededly, driven by forces well beyond merely biotechnology). ${ }^{91}$ This is undesirable because the methods of utilizing this surplus, feeding it to cows or converting it into processed foods, lead to risks to the environment and human health. ${ }^{92}$

Many of the benefits of GMOs directly address these problems. First, GM technology lends itself to application in any number of organisms. $^{93}$ The development of more varieties of GM crops could lead to an increase in agricultural diversity. Second, GMOs can require less pesticide and can produce higher yields. ${ }^{94}$ One can logically conclude that more efficient crop production per acre will permit freeing up of fields for other purposes, such as conservation. The total usage of fertilizer and other inputs thus may well decrease. Third, the problems associated with the usage of crop surplus might be alleviated by novel

88. Ahmed, supra note 29 , at 146-47.

89. Id. at 143; see also PollaN, supra note 14 , at $41-46$ (describing nitrate fertilizer use on com).

90. See supra notes $36-39$ and accompanying text.

91. See supra notes $40-41$ and accompanying text.

92. See supra notes $42-51$ and accompanying text.

93. See Degnan, supra note 54 ("Scientists can now easily transfer genes from one source into bacteria, plants, or animals of totally different origin.").

94. See supra note 73 and accompanying text. 
GMOs. For example, one can imagine the development of a new GM crop that could be used to feed cows but that does not cause the acidification of their digestive systems like corn does. ${ }^{95}$

On the other hand, the introduction of GMOs into agriculture might provide a method for industrial agriculture to become even more "industrial." This hypothetical progression would result primarily from the capacity of GMOs to grow crops more efficiently and easily. Thus, although such a proposition is counterintuitive and seemingly absurd, the agricultural model might have more negative impact thanks to increases in efficiency. First, agricultural diversity might diminish yet further by the development of particular GM crop varieties that serve the needs of the food industry extremely well. In a worst case, if perhaps fanciful scenario, every American farmer would cultivate a single variety of GM crop that can grow under practically any condition and can be used for any purpose. Second, although more efficient crop production would appear to enable the freeing up of fields and resources for other purposes, the result might alternatively be the use of "freed-up" fields for the same purpose, growing GM crops, ultimately necessitating the use of more inputs like chemical fertilizer. Third, this in turn could lead to an even larger crop surplus that the food industry could find cost-effective, but environmentally and socially expensive, methods of utilizing.

Although attempting to predict the effects that GM crops will have on industrial agriculture requires a fair degree of speculation, the law should anticipate the impact of new technology on the environment and human well-being. The next subpart inquires into how the law currently handles GM technology as a precursor to a discussion of whether the patent law can serve as a tool for harnessing the potential of GMOs while also addressing its various risks.

\section{The Current Regulation of GMOs}

A brief iook at the history and current strategy of GMO regulation is appropriate before exploring the implications of modifications to patent law. The rise of the use of recombinant DNA techniques in the early 1970s triggered public concerns, community bans on genetic research, protests, and government discussions of the technology. ${ }^{96}$ Scientists initially opted to self-regulate the technology in an effort to avoid

95. See supra notes 43-44 and accompanying text.

96. Emily Marden, Risk and Regulation: U.S. Regulatory Policy on Genetically Modified Food and Agriculture, 44 B.C. L. REV. 733, 736 (2003). 
governmental regulation. ${ }^{97}$ In 1975 , a conference of scientists at the Asilomar Conference Center in Pine Grove, California, led to a set of guidelines, later adopted by the National Institutes of Health, which helped quell public concerns and promote safe research. ${ }^{98}$

The United States emerged as a leader in biotechnology by the 1980s, and the Reagan Administration was reluctant to discourage this tendency. ${ }^{99}$ Nonetheless, concerns about public health and environmental safety accompanied the imminence of the creation of GM foods ${ }^{100}$ and led to the recognition that regulation was necessary. ${ }^{101}$ Consequently, the White House Office of Science and Technology Policy promulgated a finalized version of the Coordinated Framework for Regulation of Biotechnology in $1986 . .^{102}$ The Coordinated Framework specified that GM products were not inherently dangerous and that their regulation would occur under existing statutes, which became law decades before the advent of GM technology. ${ }^{103}$ This decision indicates a belief that GM products are not significantly different from their conventional counterparts. ${ }^{104}$ Under the scheme established by the Framework, the Food and Drug Administration (FDA) regulates GMOs that become food or drugs, the United States Department of Agriculture (USDA) regulates GMOs in relation to the protection of existing crops, and the Environmental Protection Agency (EPA) regulates GM-related pesticide products. ${ }^{105}$

The approach embodies the idea that GM technology is just the next step in an age-old practice of breeding and selection. ${ }^{106}$ One example is the FDA's policy on GM Foods, which presumes that GM foods are essentially the same as their non-GM counterparts. ${ }^{107}$ Under the authority of the Federal Food, Drug, and Cosmetic Act ${ }^{108}$ the FDA considers GM products to be food additives for purposes of regulation

\footnotetext{
97. Id. at 736-37.

98. Bratspies, supra note 1, at 378; Marden, supra note 96 , at 737.

99. Marden, supra note 96 , at 737.

100. Id.

101. Mandel, supra note 3, at 2216.

102. Id.

103. Id. at 2167,2216 .

104. Id. at 2217 .

105. Id. at 2216-17; Marden, supra note 96, at 739 .

106. See Applegate, supra note 2, at 232 (noting that two major assumptions of the Coordinated Framework reflect the idea "that GM technology is simply a continuation of existing breeding and selection technology").

107. Id.

108. Mandel, supra note 3, at 2218 (citing 21 U.S.C. $§ \S 301-399$ (2003)).
} 
because no provisions expressly cover GM foods. ${ }^{109}$ However, substances that are "generally recognized as safe" (GRAS) are not subject to FDA approval, and the manufacturer rather than the FDA determines whether the substance is GRAS. ${ }^{10}$ Because the FDA does not view GM foods as substantially different, it does not require that GM foods be labeled as such. ${ }^{111}$

The details of the complex regulatory scheme currently covering GM foods are beyond the scope of this Comment. ${ }^{12}$ For our purposes, there are two relevant points regarding regulation. First, the U.S. Congress does not appear to be receptive to efforts to overhaul the existing regulatory structure governing GMOs. ${ }^{113}$ Second, commentators argue that the existing multiagency regulatory strategy is unsatisfactory to optimally foster the advancement of GM technology while also addressing its various risks. ${ }^{114}$ Whatever the status and future of the direct regulation of GMOs, there may be other legal tools for promoting positive agriculture. One such tool is the patent law.

\section{PATENT LAW: THEORY AND REQUIREMENTS}

\section{A. Theory Behind Patent Law: Incentive to Innovate}

The United States Constitution explicitly grants Congress the power "[t]o promote the Progress of Science and useful Arts, by securing for limited Times to Authors and Inventors the exclusive Right to their respective Writings and Discoveries." 15 Congress exercised this power by creating the Patent Act (the Act). ${ }^{116}$ Section 101 of the Act provides: "Whoever invents or discovers any new and useful process, machine, manufacture, or composition of matter, or any new and useful

\footnotetext{
109. $l d$.

110. Id. at $2218-19$.

111. Id. at 2219 .

112. For a comprehensive overview of the scheme, see generally Marden, supra note 96

113. See, e.g., Debra M. Strauss, The International Regulation of Genetically Modified Organisms: Importing Caution into the U.S. Food Supply, 61 FOOD \& DRUG L.J. 167, 188 (2006) ("Congress does not appear to be supporting initiatives to address food safety concerns and to
} tighten the regulatory process for bioengineered food in the United States.").

114. See, e.g., Mandel, supra note 3, at 2258-59 (arguing that new regulation is required to "optimally reap the potentially spectacular health, environmental, and economic benefits of [nextgeneration] biotechnology advances" in order to prevent society from facing "inefficient costs and delays and unnecessary risks").

115. U.S. ConST. art. I, $\S 8$, cl. 8 .

116. 35 U.S.C. $\$ \S 1-376(2000)$. 
improvement thereof, may obtain a patent therefor, subject to the conditions and requirements of this title."117

The constitutional language providing for patents indicates that the purpose of patents is to encourage inventors to innovate: Congress can give exclusive rights over patents "to promote the Progress of . . . useful Arts." "18 The theory behind patents acknowledges that inventions are expensive to create and difficult to control once they are available to the public. ${ }^{119}$ Without patent protection, inventors would have little incentive to spend resources coming up with and marketing new products. ${ }^{120}$ Thus, "[p]atent law provides a market-driven incentive to invest in innovation, by allowing the inventor to appropriate the full economic rewards of her invention."121

However, the government does not hand out patents simply for the sake of inventors. ${ }^{122}$ Rather, "the Constitution places the rewards to inventors in a secondary role. It makes the public interest the primary concern in the patent system." "23 Given that patents exist to drive innovation, but for the ultimate benefit of the public, this Comment proposes that the public interest now demands a directed incentive to innovate towards improving future agriculture.

\section{B. Requirements of Patentability}

An invention must satisfy five substantive requirements to successfully receive patent protection from the Act: novelty, nonobviousness, disclosure, patentable subject matter, and utility. ${ }^{124}$ The novelty requirement limits patent protection to inventions that are truly new, as analyzed under a set of technical rules. ${ }^{125}$ The nonobviousness requirement adds to this concept, requiring that the invention represent a significant step forward in the inventive process, rather than a trivial

117. Id. $\$ 101$.

118. U.S. CONST. art. I, $\S 8, \mathrm{cl} .8$ (emphasis added).

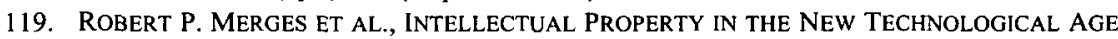
127 (4th ed. 2006).

120. Id.

121. Id.

122. See Aronson v. Quick Point Pencil Co., 440 U.S. 257, 262 (1979) (listing the purposes of the patent system).

123. United States v. Line Material Co., 333 U.S. 287, 320 (1948) (Douglas, J., concurring).

124. 35 U.S.C. $\S \S 101-103$ (2000); MERGES ET AL., supra note 119, at 124; Andrew W. Torrance, An Extinction Bar to Patentability 25 (Sept. 15, 2006) (unpublished manuscript, on file with author).

125. MERGES ET AL., supra note 119 , at 124, 185-86 (citing $\S 102$ ). For a more detailed description of the novelty requirement, see $i d$. at 185-214. 
addition to existing technology. ${ }^{126}$ The disclosure requirement seeks to ensure that the public receives its end of the "patent bargain"; society bears the costs of granting the inventor a monopoly over the invention during the patent term in exchange for the benefits of innovation, but only if the inventor provides a description of the invention sufficient to enable "one of ordinary skill in the art" to make and use the invention as soon as the patent term ends. ${ }^{127}$

A fourth requirement, subject matter, addresses what types of inventions may be patentable. ${ }^{128}$ The language of $\S 101$ appears to establish categories of patentable subject matter by limiting protection to inventions that can be described as "process[es]," "machine[s]," "composition[s] of matter," or improvements of those things. ${ }^{129}$ The rise of modern biotechnology, however, brought into question how strictly patent examiners should follow these categories, particularly with respect to inventions that involved living organisms. The Court in Diamond $v$. Chakrabarty reviewed the patentability of a "human-made, genetically engineered bacterium ... capable of breaking down multiple components of crude oil." 130 The United States Patent and Trademark Office (USPTO) denied a patent on the grounds that microorganisms are "products of nature" and that $\S 101$ does not allow patenting of living things. ${ }^{131}$ The Supreme Court of the United States analyzed the language of $\S 101$ : "In choosing such expansive terms as 'manufacture' and 'composition of matter,' modified by the comprehensive 'any,' Congress plainly contemplated that the patent laws would be given wide scope."132 The Court held the scope of potentially patentable subject matter includes "anything under the sun that is made by man." 133 The Court confirmed this interpretation in 2001: "'the relevant distinction was not between living and inanimate things, but between products of nature, whether living or not, and human-made inventions." "134 38 .

126. Id. at 124 (citing $\S 103$ ). For a more detailed description of nonobviousness, see $i d$. at 214

127. Id. at 124-25 (citing $\S 112$ ); Torrance, supra note 124, at 25-26 (citing and discussing $\S$ 112).

128. MERGES ET AL., supra note 119 , at 128.

129. 35 U.S.C. $\S 101$ (2000).

130. Diamond v. Chakrabarty, 447 U.S. 303, 305 (1980).

131. Id. at 306 .

132. Id. at 308 .

133. Id. at 309 (quoting S. REP. No. 82-1979, at 5 (1952) (Conf. Rep.); H.R. REP. No. 82-1923, at 6 (1952) (Conf. Rep.)).

134. J.E.M. Ag Supply, Inc. v. Pioneer Hi-Bred Int'l, Inc., 534 U.S. 124, 130 (2001) (quoting Chakrabarty, 447 U.S. at 313). 
The Chakrabarty decision extends protection to nearly anything that is not naturally occurring and can meet the other requirements of patentability. When considering how this result might shape the evolution of GM technology, a pressing question emerges: can we use another patent-law mechanism to encourage the development of only certain kinds of innovation?

\section{Variations on Utility}

The final requirement of patentability is utility. Section 101 requires that inventions be "useful" to receive patent protection. ${ }^{135}$ Indeed, the Constitution itself, when granting Congress the power to promote the progress of arts and sciences, limits such power to the progress of "useful Arts." "136 However, as the Supreme Court noted in Brenner v. Manson, "a simple, every day word [like "useful"] can be pregnant with ambiguity when applied to the facts of life."137 This statement opens the door to the conclusion that whether an invention is useful depends on the type of invention and the context in which the inventor is operating. ${ }^{138}$

\section{Utility Doctrine in General}

Without more constitutional or statutory language to offer guidance, successive court decisions interpreting the meaning of "useful" have fleshed out the utility doctrine, ${ }^{139}$ although utility issues arise relatively rarely during the examination process or infringement suits. ${ }^{140}$ Decisions that have used the utility requirement to reject patents have distinguished three general varieties of utility: general utility, specific utility, and moral utility. $^{141}$

General utility refers to the notion that the invention must address some sort of human need or problem. ${ }^{142}$ An 1890 treatise by Professor

135. 35 U.S.C. $\$ 101(2000)$.

136. U.S. CONST. art. I, $\S 8$, cl. 8 (emphasis added).

137. Brenner v. Manson, 383 U.S. 519, 529 (1966).

138. Cf. Nathan Machin, Comment, Prospective Utility: A New Interpretation of the Utility Requirement of Section 10J of the Patent Act, 87 CAL. L. REV. 421, 431 (1999) (noting, during a discussion of the interpretation of utility carved out in Brenner, that the "amount and strength of evidence necessary to prove that an invention is useful varies with the facts of each case").

139. See id. at 437 (identifying the three sources of the utility doctrine).

140. MERGES ET AL., supra note 119 , at 144.

141. Id.; see also Machin, supra note 138, at 426 (characterizing moral utility as one interpretation of general utility).

142. Machin, supra note 138 , at 433. 
William Robinson provides an example of the subject matter that does not meet this criterion: an invention that is " a mere curiosity, a scientific process exciting wonder yet not producing physical results, or [a] frivolous or trifling article or operation not aiding in the progress nor increasing the possession of the human race." "143 This warning has not translated to a very stringent barrier to patentability, though; for example, inventions whose only purpose is to entertain or amuse are "useful" under the patent code.

The second category of utility, specific utility, applies to inventions that take on a particular function and requires that the invention be able to perform that function. ${ }^{145}$ In other words, an invention is not specifically useful if it does not actually work. ${ }^{146}$ The classic example is a patent application for a perpetual motion machine: unless an applicant can rebut scientific evidence that such a feat is impossible, the USPTO will deny a patent on such an invention for lack of specific utility. ${ }^{147}$

Under these definitions, utility is usually not a terribly difficult hurdle to overcome. ${ }^{148}$ In 1966, the Supreme Court made a decision that appeared to raise the hurdle in Brenner v. Manson. ${ }^{149}$ There, the applicant sought a patent on a chemical process of making certain steroids. ${ }^{150}$ The PTO had rejected the application for lack of utility, even though the application had referenced a scientific article revealing that the steroids were undergoing investigation for potential tumor-inhibiting uses and that they were chemically related to a class of steroids that were proven to inhibit tumors in mice. ${ }^{151}$ The Court ultimately upheld the rejection, noting that Congress did not intend for patents to cover chemical products that are only really useful in the sense that scientists can run tests on them in search of a useful application, and that chemical processes are no different. ${ }^{152}$ The Court memorably explained that "a patent is not a hunting license. It is not a reward for the search, but compensation for its successful conclusion."153

143. MERgeS ET AL., supra note 119, at 155 (quoting $1 \mathrm{~W}$. ROBINSON, TREATISE ON THE LAW OF PATENTS FOR USEFUL INVENTIONS 463 (1890)) (alteration in original).

144. Id. at 155-56; Machin, supra note 138, at 433.

145. MERGES ET AL., supra note 119 , at 156.

146. Machin, supra note 138 , at 426.

147. MERGES ET AL., supra note 119, at 156.

148. Machin, supra note 138, at 436.

149. 383 U.S. 519 (1966).

150. Id. at 520 .

151. Id. at 521-22 \& n.3.

152. Id. at 535.

153. Id. at 536 . 
Brenner perhaps represents the most stringent application of the utility requirement. ${ }^{154}$ Although its application has been limited ${ }^{155}$ and its rule is not easily extended by analogy, ${ }^{156}$ Brenner stands for two important propositions. First, it shows a capacity for the law to take the utility requirement seriously. Second, it invokes the importance of the utility requirement to the original purpose of the patent system, which is to benefit the public: "The basic quid pro quo contemplated by the Constitution and the Congress for granting a patent monopoly is the benefit derived by the public from an invention with substantial utility."157 As one investigates the various meanings that courts have derived from "useful," this observation becomes particularly relevant to promoting improved GM agriculture.

\section{Moral Utility}

A third flavor of utility involves morality. Justice Story laid the foundation of the moral utility doctrine in 1817 in Lowell v. Lewis ${ }^{158}$ when he interpreted the meaning of "useful" as it appeared in the Patent Act of $1790 .{ }^{159}$ In this infringement action involving an invention related to the construction of pumps, the plaintiff claimed that the defendant's pump had to be "a better pump than the common pump" to be "useful." 160 Justice Story rejected this argument and explained: "All that the law requires is, that the invention should not be frivolous or injurious to the well-being, good policy, or sound morals of society. The word 'useful,' therefore, is incorporated into the act in contradistinction to mischievous or immoral."161 His examples of inventions flunking this test included "a new invention to poison people, or to promote debauchery, or to facilitate private assassination." 62 That same year, Justice Story echoed these observations in another patent infringement case: "[The law] simply requires, that [an invention] shall be capable of

154. MERGES ET AL., supra note 119, at 149; see also Andrew R. Smith, Comment, Monsters at the Patent Office: The Inconsistent Conclusions of Moral Utility and the Controversy of Human Cloning, 53 DEPAUL L. REV. 159, 168 (noting that the Brenner court "formulated what remains the highest authority on the scope and purpose of patentable utility").

155. Machin, supra note 138 , at 428-29.

156. MERGES ET AL., supra note 119 , at 149.

157. Brenner, 383 U.S. at 534.

158. 15 F. Cas. 1018 (C.C.D. Mass. 1817) (No. 8568).

159. Machin, supra note 138 , at 435 ; Smith, supra note 154 , at 164.

160. Lowell, 15 F. Cas. at 1019; Smith, supra note 154, at 164 .

161. Lowell, 15 F. Cas. at 1019 (quoting The Patent Act of 1790).

162. Id. 
use, and that the use is such as sound morals and policy do not discountenance or prohibit." 163

Justice Story was attempting to articulate a low utility bar to patentability. ${ }^{164}$ However, his language from Lowell appears in nearly all the subsequent applications of the doctrine, striking down patents for lack of moral utility. ${ }^{165}$ A series of çases in the late nineteenth and early twentieth centuries used the doctrine to invalidate patents on gambling devices on the theory that gambling is immoral. ${ }^{166}$ For example, the court in National Automatic Device Co. v. Lloyd held that a coinoperated machine called "Toy Automatic Race-Course," whose sole purpose was gambling in saloons, was not patentable. ${ }^{167}$ The court explained: "it is not a useful device, within the meaning of the patent law, as its use so far has been only pernicious and hurtful.,"168

As societal perceptions of morality changed and defining morally acceptable inventions became more difficult, courts became less willing to extend the moral utility doctrine. ${ }^{169}$ The practice of invalidating gambling machine patents stopped in 1977 with Ex parte Murphy. ${ }^{170}$ There, the USPTO Board of Appeals reviewed an examiner's decision to reject a patent application for a slot machine for lack of patentable utility. ${ }^{171}$ In reversing the rejection, the Board effectively ended an era of applying the moral utility doctrine to gambling machines: "we think this Office should not be the agency which seeks to enforce a standard of morality with respect to gambling, by refusing, on the ground of lack of patentable utility, to grant a patent on a game of chance if the requirements of the Patent Act otherwise have been met."

The Murphy court, in dicta, discussed another limitation of the moral utility doctrine when it reviewed what it considered to be the "guiding

163. Bedford v. Hunt, 3 F. Cas. 37, 37 (C.C.D. Mass. 1817) (No. 1217).

164. See Machin, supra note 138, at 436 ("Judicial misinterpretation of Judge Story's insightful articulation of the utility requirement as shrill moralizing obscures his real message which is that the marketplace is the ultimate arbiter of an invention's utility.").

165. Smith, supra note 154 , at 164 .

166. Juicy Whip, Inc. v. Orange Bang, Inc., 185 F.3d 1364, 1367 (Fed. Cir. 1999) (citing Brewer v. Lichtenstein, 278 F. 512 (7th Cir. 1922); Nat'l Automatic Device Co. v. Lloyd, 40 F. 89 (C.C.N.D. IIl. 1889)); Schultze v. Holtz, 82 F. 448 (C.C.N.D. Cal. 1897).

167. $40 \mathrm{~F}$. at 89-90; Smith, supra note 154 , at 165 .

168. Lloyd, $40 \mathrm{~F}$. at 90.

169. Margo A. Bagley, Patent First, Ask Questions Later: Morality and Biotechnology in Patent Law, 45 WM. \& MARY L. REV. 469, 489 (2003).

170. 200 U.S.P.Q. (BNA) 801, 803 (1977).

171. Id. at 801 .

172. Id. at 803 . 
principles"173 of moral utility as set forth in a 1903 case, Fuller $v$. Berger. ${ }^{174}$ The Fuller court discussed three possible tests to determine the utility of a Colt revolver: first, " "by balancing the good functions with the evil functions"”; second, by considering "'utility negatived by the mere fact that the thing in question is sometimes injurious to morals, or to health, or to good order"'; and third, by concluding that " "everything [is] useful within the meaning of the law, if it is used . . to accomplish a good result, though in fact it is oftener used . . . to accomplish a bad one.",175 The Fuller court concluded, and the Murphy court agreed, that the third test is the proper method of determining moral utility; the relevant question is whether the invention is capable "of 'serving any beneficial end.", 176

In the fairly recent case Juicy Whip, Inc. v. Orange Bang, Inc., the Court of Appeals for the Federal Circuit declined to use the moral utility doctrine to strike down a patent on a juice machine that displayed a nonjuice liquid in a tank to deceive consumers into believing that the juice was a "pre-mix" machine when in fact it was a "post-mix" machine. ${ }^{177}$ The court reasoned that " $[\mathrm{t}]$ he fact that one product can be altered to make it look like another is in itself a specific benefit sufficient to satisfy the statutory requirement of utility" and that "[ $t]$ he fact that customers may believe they are receiving fluid directly from the display tank does not deprive the invention of utility.",178

Murphy and Juicy Whip represent a departure from the moral utility doctrine, but they do not indicate its complete extinction. ${ }^{179}$ Courts can interpret both holdings narrowly. ${ }^{180}$ The Murphy court's reasoning was that it no longer had any basis on which to insist that gambling was immoral, not that utility does not incorporate morality, and it limited its holding to gambling-related morality. ${ }^{181}$ Likewise, the Juicy Whip court declined to follow cases that invalidated patents over products that imitated higher-quality versions of those products. ${ }^{182}$ The particular

\footnotetext{
173. Id. at 802 .

174. 120 F. 274 (7th Cir. 1903).

175. Murphy, 200 U.S.P.Q. (BNA) at 802 (quoting Fuller, 120 F. at 275).

176. Id. (quoting Fuller, $120 \mathrm{~F}$. at 275) (emphasis omitted).

177. 185 F.3d 1364, 1365-68 (Fed. Cir. 1999).

178. Id. at 1367 .

179. See Benjamin D. Enerson, Protecting Society from Patently Offensive Inventions: The Risk of Reviving the Moral Utility Doctrine, 89 CORNELL L. REV. 685, 691 (2004) (arguing that the moral utility doctrine is not "completely dead").

180. See Smith, supra note 154, at 187-88 (stressing that the purposes of the two challenged patents became or were legal).

181. Murphy, 200 U.S.P.Q. at 803.

182. Juicy Whip, 185 F.3d at 1367 (citing Scott \& Williams v. Aristo Hosiery Co., 7 F.2d 1003
} 
utility in Juicy Whip (making customers believe they are buying premixed juice) may represent a threshold beyond which the moral utility doctrine still applies. ${ }^{183}$

\section{USPTO Utility Guidelines}

The USPTO promulgates the Manual of Patent Examination Procedure (MPEP) as a reference of the practices and procedures it uses during patent prosecution. ${ }^{184}$ One section of the MPEP creates guidelines for patent examiners deciding whether an invention is useful (Utility Guidelines). ${ }^{185}$ Although these Utility Guidelines are not legally binding, they "establish the policies and procedures to be followed by the Office personnel in the evaluation of any patent application for compliance with the utility requirement[]." ${ }^{186}$ According to the guidelines, the invention's asserted utility must be "specific, credible, and substantial." 187 Credible utility means that the invention must not be farfetched, like a perpetual motion machine. ${ }^{188}$ Specific utility, in this context, requires that the asserted utility have a specific use. ${ }^{189}$ The USPTO training materials give the example of a gene sequence that can be used to identify a disease; the Utility Guidelines require that the applicant specify which disease the sequence identifies. ${ }^{190}$ Substantial utility excludes the notion of "throw-away utilities," such as using transgenic mice as snake-food or using a complex invention as landfill. ${ }^{19}$

This set of utility subrequirements is not necessarily a direct reflection of the utility doctrine as it developed through successive judicial interpretations of the word "useful." The current Utility Guidelines were established in response to policy concerns regarding the "fragmentation of individual ownership claims,","92 whereby "[a]

(2d Cir. 1925); Rickard v. Du Bon, 103 F. 868 (2d Cir. 1900)).

183. See Smith, supra note 154 , at 188 (identifying one application of the moral utility doctrine that might survive Juicy Whip).

184. U.S. Patent \& TRademark Office, U.S. DeP'T Of Commerce, Manual of Patent EXAMINING Procedure, Foreword (8th ed., rev. 5, Aug. 2006), available at http://www.uspto.gov/ web/offices/pac/mpep/indext.htm [hereinafter MANUAL].

185. Id. $\S 2107(\mathrm{II})$.

186. Id. $\S 2107(\mathrm{I})$.

187. MERGES ET AL., supra note 119, at 152 (quoting 2001 version of MANUAL, supra note 184, set forth in 8 th edition at $\$ 2107$ (II)(A)(3)).

188. Id.

189. Id.

190. Id.

191. Id. at 152-53 (quoting 2001 version of MANUAL, supra note 184, set forth in 8 th edition at $\S 2107(\mathrm{II})(\mathrm{B})(\mathrm{i}))$.

192. Id at 153. 
proliferation of intellectual property rights upstream may be stifling lifesaving innovations further downstream in the course of research." "193 This premise stems from "the tragedy of the anticommons" theory: "In an anticommons ... multiple owners are each endowed with the right to exclude others from a scarce resource, and no one has an effective privilege of use. When there are too many owners holding rights of exclusion, the resource is prone to underuse-a tragedy of the anticommons." 194 The current formulation of the Utility Guidelines thus illustrates "how large policy issues are often played out in the details of patent rules and doctrines"195 and, specifically, how concerns about scientific research can inform the interpretation of utility.

In summary, inventions must be "useful" in order to receive patent protection. This requirement is consistent with the overall goal of the patent system to benefit the public. On the whole, utility has been an easy requirement to satisfy, so long as the invention gives something back to the public and actually works. However, in cases like Brenner and older cases that found gambling machines to be immoral, the utility standard has been used to limit patentability for particular policy reasons. Further, the current USPTO guidelines were adopted in response to specific concerns about scientific research. The history and current manifestation of the utility doctrine leave open the possibility of judicial tailoring of the utility requirement to address the needs of agricultural biotechnology.

\section{A NEW UTILITY STANDARD FOR GMO-RELATED AGRICULTURAL INVENTIONS}

So far, this Comment has visited a number of related concepts. First, it revealed the United States' intimate relationship with corn to support the notion that while technological developments have greatly expanded the volume of agricultural output, this expansion comes with costs in the form of decreased agricultural diversity, harm to the environment, fewer farming jobs, human and animal health hazards related to using corn as

193. Michael A. Heller \& Rebecca S. Einsenberg, Can Patents Deter Innovation? The Anticommons in Biomedical Research, 280 SCIENCE 698, 698 (1998), quoted in MERGES ET AL., supra note 119 , at 153 .

194. Michael A. Heller, The Tragedy of the Anticommons: Property in the Transition from Marx to Markets, 111 HARV. L. REV. 621,624 (1998). Merges et al. note, however, that recent empirical studies do not really support the anticommons theory, suggesting that scientists are willing to share their technologies even if they hold the right to exclude others. MERGES ET AL., supra note 119, at 153.

195. MERGES ET AL., supra note 119 , at 153. 
feed, and unhealthy diets. ${ }^{196}$ Second, an examination of the history of GMOs and their effects, good and bad, and a brief summary of the regulatory scheme behind biotechnology prompted an analysis of patent law's purpose and requirements. ${ }^{197}$ Having considered how the utility requirement has received customized interpretation in the past and how policy concerns about scientific research have already shaped the USPTO Utility Guidelines, this Comment now proposes a heightened utility standard for agricultural GMO patents. It will flesh out a basic argument, distinguish which agricultural goals the patent law should aspire to promote, explore possible methods of adopting such a standard, and, finally, weigh countervailing considerations against the adoption of the new utility requirement.

\section{A. The Basic Argument}

Admittedly, there are many contributing factors to the current state of American agriculture that Michael Pollan's depiction of corn represents; the introduction of GM technology is only one dimension of a complicated industry. ${ }^{198}$ Nonetheless, GM technology will continue to play a large role in the evolution of modern agriculture, ${ }^{199}$ and the law should anticipate its effects. GM technology poses opportunity for immense improvements to agriculture as well as terrifying dangers. ${ }^{200}$ Whereas the current regulatory framework may or may not be an adequate method of promoting the promise of GM technology while protecting against its risks, ${ }^{201}$ the patent system might be an independent legal tool for advancing sound agricultural policy. If the theory behind the patent system is to encourage inventors to innovate, ${ }^{202}$ then a guided patent system can channel innovation in a positive direction. Judges and patent examiners have in the past interpreted the meaning of one requirement of patentability, utility, to accommodate the public interest. ${ }^{203}$ The public interest in sound agriculture now compels such treatment of GM-related inventions: GM inventions tending to have an impact on agriculture should not be considered "useful" within the

196. See supra Part II.A.

197. See supra Parts II.B, II.C, II.D, III.

198. See, e.g., POLlaN, supra note 14, at 48-56 (discussing the history of the "perverse economics of agriculture").

199. See supra notes $63-66$ and accompanying text.

200. See supra Part II.B.2.

201. See supra Part II.D.

202. See supra Part III.A.

203. See supra Part III.C. 
meaning of the useful Arts clause of the Constitution and $\S 101$ of the Patent Act unless they promote certain agricultural goals. As a result of the adoption of such a standard, the biotechnology industry would concentrate research and development in technology that is more likely to be patentable, the very technology that promotes these goals. The ultimate intended result would be an improved state of agriculture.

\section{B. Criteria for Identifying "Useful" GMOs}

An important step in creating a new utility standard is dissecting the macroscopic issue GMOs present into concrete, distinct goals. This subpart identifies three fundamental goals that patent examiners and courts could incorporate into criteria (the Criteria) for judging whether biotechnological inventions relating to agriculture meet the utility requirement.

\section{Sustainability}

One of the most striking issues that the corn monoculture evokes, and which GM technology can affect, is the idea of "sustainability." As one commentator argues, "[t]he popular debate over the use of biotech crops is, at its core, a debate over sustainability."204 Just what "sustainability" means, however, is not so evident. Sustainability can be a vague and ambiguous concept. ${ }^{205}$ Authors have dedicated entire works to finding a workable definition that minimizes ambiguities. ${ }^{206}$ The most common definition appeared in 1987 in a report by the World Commission on Environment and Development (the Brundtland Report): sustainable development is "development that meets the needs of the present without compromising the ability of future generations to meet their own needs.",207 From there, "the term has taken on a life of its own, finding diverse expression in all manner of environmental treaties, trade agreements, international aid programs, presidential council reports, state and local planning schemes, corporate mission statements, investment fund charters, NGO policy documents, and so on.",208

204. Daniel M. Krainin, Biotech Crops, Biosafety Protocol: Genetically Modified Sustainability?, NAT. RESOURCES \& ENV'T, Fall 2004, at 63, 63.

205. Sanford E. Gaines, Sustainable Development and National Security, 30 WM. \& MARY ENVTL. L. \& POL'Y REV. 321,339 (2006).

206. Id. at 340 .

207. Krainin, supra note 204 (quoting WORLD COMM'N ON ENV'T \& DEV., OUR COMMON FUTURE (1987)).

208. Douglas A. Kysar, Sustainable Development and Private Global Governance, 83 TEX. L. 
The Brundtland definition provides a general guideline to start the process of developing a sustainability criterion of practical use to patent examiners and courts. As a general proposition, courts and the USPTO should not consider inventions to be "useful" if, in enhancing the current generation's ability to meet its agricultural needs, they are likely to compromise future generations' ability to meet their own agricultural needs. Likewise, an invention should be presumed to be "useful" if it appears that it will improve future generations' ability to meet their agricultural needs while simultaneously aiding the current generation's agricultural needs. The challenge for judges or patent examiners will be determining when a technology poses a risk of being unsustainable under this definition.

One place the implementers of the new utility requirement might turn for guidance in establishing a workable framework are the principles embraced by the Cartagena Protocol on Biosafety (Cartagena Protocol), an international treaty that regulates GM crops. ${ }^{209}$ Adopted in 2000 as part of the United Nations' Convention on Biological Diversity, the Cartegena Protocol became effective in 2003 and governs transportation of GM products across borders of nations that are a party to it (a group that does not include the United States). ${ }^{210}$ One commentator notes, "[s]ustainable development is a fundamental unifying principle in ... the Cartagena Protocol."211 Its objective is "to contribute to ensuring an adequate level of protection in the field of the safe transfer, handling and use of living modified organisms resulting from modern biotechnology that may have adverse effects on the conservation and sustainable use of biological diversity." 212 Importing the spirit of an agreement that many nations in the world have ratified, a framework for deciding which inventions will promote sustainability might reflect ideas from the Cartagena Protocol.

Even if a workable definition of sustainability were developed, the uncertainty surrounding how an invention would be put to commercial use demonstrates one of the serious shortcomings of using the utility requirement to promote a substantive outcome. This shortcoming was

REV. 2109, 2115 (2005).

209. Christina L. Richmond, Genetically Modified Crops in the Philippines: Can Existing Biosafety Regulations Adequately Protect the Environment?, 15 PAC. RIM L. \& POL'Y J. 569, 576 (2006).

210. Krainin, supra note 204 , at $66-67$.

211. Id. at 67.

212. The Secretariat of the Convention on Biological Diversity, Cartagena PROTOCOL ON BIOSAFETY TO THE CONVENTION ON BIOLOGICAL DIVERSITY art. 1 (2000), available at http://www.biodiv.org/doc/legal/cartagena-protocol-en.pdf. A "living modified organism" is a GMO that is capable of reproducing, such as a GM seed. Krainin, supra note 204, at 67. 
recognized by the court in Ex parte Murphy when it reviewed what it regarded as the proper test for moral utility as laid out in Fuller $v$. Berger: whether the invention can be put to any beneficial use. ${ }^{213}$ For example, imagine a new GM breed of corn that is engineered to produce forty normally sized ears of corn per stalk; the plant is otherwise normal except that its peculiar root system causes soil erosion at ten times the normal rate. At first glance, the invention appears to flunk the sustainability criterion: a judge reviewing the application for a patent on such a GMO, and hearing evidence tending to show the above facts, could reject the patent on the grounds that it is likely to deprive future generations of the soil they require to meet their own needs. On the other hand, the very same corn plant might be used in such a way as to promote sustainability. Suppose, for example, a farmer, very concerned about future generations' soil needs, decided to replace his conventional corn growing practices with a system of raising the forty-eared corn plant only in large greenhouses that prevented soil loss. Assuming the farmer would only have had access to the new GMO as a result of the incentives bestowed upon the inventor by a patent, a judge's decision to deny a patent for the invention might end up actually frustrating the goal of sustainability.

\section{Environmental Health}

While impacts on the environment represent one important aspect of sustainability, the new utility requirement could seek to promote an environmental health goal that is distinct from sustainability. Its focus would not be how new inventions can ensure that future generations are not deprived of the natural resources required to meet their needs, but how to protect the environment in its natural state, free from the impact of human beings. The wisdom of such a goal is embodied in the decision of Congress to enact the Wilderness Act, ${ }^{214}$ which recognizes the numerous benefits of protecting certain lands from the encroachment of any influence of man. ${ }^{215}$ Following this reasoning, the patent system could refuse to consider inventions that pose substantial risk to the wellbeing of natural habitats as "useful" for purposes of patentability.

For example, assume that nitrate fertilizer runoff has been proven to cause severe algae growth in the Gulf of Mexico and that such algae

\footnotetext{
213. See supra notes $170-76$ and accompanying text.

214. 16 U.S.C. $\$ \S 1131-1136(2000)$.

215. See id. $\$ 1131$ (a), (c) (creating a National Wilderness Preservation System and defining "wilderness").
} 
growth is becoming larger and threatens to destroy the habitat of a rare species of fish. Assume also that it can be shown that the above fortyeared corn plant requires several times the normal amount of nitrate fertilizer to grow, and that it is economically logical to raise the corn despite the increased fertilizer costs. The courts and the USPTO could choose to deny patent protection to such a GMO for lack of utility.

\section{Public Health}

A third goal that the utility requirement could encompass is the straightforward notion that an agricultural system should not endanger human health. Patent applications covering inventions whose purported utility involves human consumption could be denied, unless the applicant can show there is no substantial threat to public health, on the grounds that such an invention is not "useful." In formulating a criterion that judges an invention's potential impact on public health, it is necessary to distinguish between the different types of risks that GMOs pose. For example, as described above, the practice of growing huge amounts of corn has amounted to an American diet consisting of high proportions of processed foods and cheap calories like those coming from high-fructose corn syrup. This diet may be responsible for the obesity epidemic in America. Insofar as GMOs will enhance our ability to produce corn efficiently, and provided that the processed food industry will absorb an increased input of raw materials in its continual development of complex food systems, GMOs may present a public health risk through their indirect boost in the amount of unhealthy foods available to consumers. However, this cause-and-effect chain is probably too attenuated to justify the denial of a patent on utility grounds.

A more direct type of public health concern is that a GM food ingredient itself will, by virtue of some physical difference between it and its conventional counterpart, cause adverse health effects when consumed. A study by the World Health Organization identified these risks as including: "direct health effects (toxicity), tendencies to provoke allergic reaction (allergenicity), specific components with toxic properties, the stability of the inserted gene, nutritional impact," and the risk that genes from GM foods "could transfer to bacteria in the gastrointestinal tract or to cells of the body and cause negative health effects," such as antibiotic resistance due to transfer of antibioticresistant marker genes. ${ }^{216}$ Although the FDA is charged with protecting

216. Strauss, supra note 113 , at 169-70. 
the public from such dangers, the new utility requirement could require inventors to show that their inventions will not bring about such hazards before awarding a monopoly over the technology.

\section{B. Implementation}

Assuming that tailoring the utility requirement is worthwhile, an inherent challenge to such a proposal is implementing the change. How does the patent law adopt a new utility standard? The government could put the new standard into operation through the legislative, executive, or judicial branch. This subpart inquires into methods of implementing a utility requirement that limits patent protection to inventions meeting the Criteria and explores one procedural issue that will need to be addressed.

\section{Legislative}

One way to implement a new utility standard would be for Congress to simply enact a new statutory provision limiting patent protection to inventions that meet the Criteria. This approach would have the advantage of giving Congress the opportunity to explicitly list the criteria it deems most important as a clear guide to patent examiners, practitioners, researchers, and biotech companies that invest in GM innovation.

This sort of legislative action would not be unprecedented. Congress has specifically exempted from patent protection inventions that are "useful solely in the utilization of special nuclear material or atomic energy in an atomic weapon." 217 Public policy concerns about GM technology might also be a basis for statutorily limiting patent protection to inventions that satisfy the Criteria, whether by declaring them outside the scope of patentable subject matter or by more precisely defining "useful."

\section{Administrative}

The USPTO is an administrative agency, established within the Department of Commerce. ${ }^{218}$ It has authority under the Patent Act to establish regulations for the "conduct of [its] proceedings." 219 The 
USPTO could make regulations designed to ensure that the patents it grants covering biotechnological inventions do not frustrate the purposes of the Criteria. It might alternatively establish procedural advantages, such as accelerated prosecution, for inventions that are likely to promote the purposes of the Criteria.

Additionally, the USPTO promulgates the MPEP, the guide that helps patent examiners make determinations regarding the patentability of applicants' inventions. ${ }^{220}$ The USPTO could revise the MPEP to encourage examiners to scrutinize applications for their utility under the new standard that incorporates the Criteria. The Utility Guidelines have been adjusted in the past to meet the concerns of the scientific community ${ }^{221}$ - the USPTO thus has the capacity to adjust its literature to reflect changes it deems necessary to carry out its office of granting patents to "useful" inventions.

\section{Judicial}

Federal courts frequently encounter cases in which they must decide whether a given invention deserves a patent. ${ }^{222}$ These decisions may result from patent infringement suits ${ }^{223}$ or appeals by applicants dissatisfied with the USPTO's denial of patent protection. ${ }^{224}$ Utility is one of the grounds on which judges can find a patent invalid. Facing challenges to the utility of patented biotechnological inventions, courts should take into account the public interest in promoting sustainable and environmentally and publicly safe agriculture. In fact, one might even argue that courts should have been reading the Criteria into the utility requirement since Chakrabarty and the advent of GMO patents.

This interjection of public policy considerations by courts could take two forms: (1) Invalidation of patents covering technology that poses a serious risk of frustrating one or more of the Criteria, as shown by evidence put on by the patentee and the USPTO (scientific studies, expert-witness testimony, past problems with similar technology); (2) Presumptive validation of patents that will likely promote the goals of

220. MANUAL, supra note 184 .

221. See supra notes $192-95$ and accompanying text.

222. See 28 U.S.C. $\$ 1338$ (a) (2000) ("The district courts shall have original jurisdiction of any civil action arising under any Act of Congress relating to patents ....").

223. E.g., Juicy Whip, Inc. v. Orange Bang, Inc., 185 F.3d 1364, 1365-66 (Fed. Cir. 1999).

224. See 35 U.S.C. $\S \S 134,141$ (2000) (enabling applicants to appeal USPTO decisions to the Board of Patent Appeals and Inferences or to the Court of Appeals for the Federal Circuit); 35 U.S.C. $\S 145(2000)$ (enabling appeals of decisions of the Board of Patent Appeals and Inferences to the United States District Court for the District of Columbia). 
the Criteria, as shown by the same evidentiary factors. Future Examination Guidelines, USPTO procedures, and court decisions would reflect the change in the law based on precedent.

\section{Burden of Proof}

The Federal Circuit has articulated a two-step test for deciding whether a patent applicant satisfies the utility requirement ${ }^{225}$ : "the [USPTO] has the initial burden of challenging a presumptively correct assertion of utility in the disclosure. Only after the [USPTO] provides evidence showing that one of ordinary skill in the art would reasonably doubt the asserted utility does the burden shift to the applicant to provide rebuttal evidence sufficient to convince such a person of the invention's asserted utility.,226

One procedural challenge to modifying the utility requirement to incorporate the Criteria is determining whether this framework should still apply. Should the initial burden be on the applicant rather than the USPTO? Moreover, what standard of proof should be required-for example, "preponderance of the evidence" or "beyond a reasonable doubt." Should the standard of proof be the same for each of the Criteria or differ depending on the degree of uncertainty associated with each Criterion? These are questions that the implementers of the new utility requirement would need to address.

A "clear and convincing" standard, placed on the applicant, appears to be an appropriate solution. The applicant, having spent resources to research and develop the new technology, might be expected to have greater access to information relevant to that technology's potential impact on sustainability, the environment, and human health. Moreover, it seems fair that, standing in a position to reap the benefits of a monopoly over the invention, the applicant should bear the initial burden of showing that the invention meets the Criteria. Finally, a "clear and convincing" standard seems to catch the optimal gray area between a standard that is too stringent and one that is too permissive. A "beyond a reasonable doubt" standard is likely too stringent in a field such as biotechnology, where it is admittedly difficult to know what effects an invention is going to have at the patent application stage. Likewise, a

225. Donald S. Chisum et Al., PRinciples of PATENT LAW 749 (3d ed. 2004) (citing In re Brana, 51 F.3d 1560, 1566 (Fed. Cir. 1995)).

226. Brana, 51 F.3d at 1566 (citation omitted). 
"preponderance" standard may simply be too easy to satisfy, allowing too many inventions that flunk the Criteria to receive patents.

\section{Counterarguments and Drawbacks}

An immediate argument against the necessity of a heightened GM standard is that a patent merely creates a right to exclude, not an "affirmative right to make, use, or sell anything."227 Thus, even if an inventor obtained a patent on an invention whose implementation would clearly violate federal regulation, he would not be able to lawfully exercise the invention. Why should we even need to redefine what is "useful" at the patent stage, when later regulation will prohibit undesirable uses of the invention? Moreover, why will market economics not simply reject inventions that society does not find useful, either because it does not meet one of society's needs or because society finds it environmentally, medically, or morally repugnant?

Three responses meet these arguments. First, as for the later protection of regulation, the current regulatory framework may not be an adequate measure to protect against the unique harms of GM technology. ${ }^{228}$ Second, the market alone is not a strong enough check against potential harms of GM agriculture, because the consumer sits several steps removed from the process by which his food is grown. The average consumer may consistently buy cheap tortillas, produced through unsound means, before more expensive ones produced through more desirable means, perhaps even having the knowledge that the reduction in price comes with environmental or social costs. Third, regulation and economics do not necessarily provide direct incentive for inventors to innovate. An inventor might spend time and money inventing something, wholly unaware that it will later be found to violate some regulation or that for unexpected reasons it will not sell. On the other hand, the purpose of the patent law is to encourage invention, and it follows that it has a more direct influence on why inventors act the way they do. Finally, even if regulation and economics verge on adequacy, a supplemental legal measure is called for when the stakes are as high as they are.

A second possible objection to the new utility requirement is that it flies in the face of language adopted by the Federal Circuit in Juicy Whip from an 1880 Supreme Court case, Webber v. Virginia: "Congress never

227. Leatherman Tool Group, Inc. v. Cooper Indus., Inc., 131 F.3d 1011, 1015 (Fed. Cir. 1997).

228. See supra note 114 and accompanying text. 
intended that the patent laws should displace the police powers of the States, meaning by that term those powers by which the health, good order, peace and general welfare of the community are promoted.",229 This statement would seem to contradict the idea that the federal patent law can consciously promote policy goals relating to sustainability, the environment, and public health. However, this language appears in dictum in a case that struck down a patent for reasons unrelated to the concerns of GM agriculture. Moreover, it is not certain that the U.S. Supreme Court would still find this language meaningful. Finally, the decision to treat GMO-related inventions differently with respect to the meaning of "useful" is not necessarily a displacement of state police powers by the federal government. Rather, the federal government might be simply exercising its authority under the Constitution to promote the progress of those arts that it finds useful. The Framers could hardly have foreseen the introduction of GM technology centuries ago when creating the Constitution; it follows that what they meant by "useful" cannot have a single definition over time. By choosing to qualify what may be patented by inserting the word "useful," the Framers, as well as Congress in drafting $\S 101$ of the Patent Act, wanted to ensure that the governmental resources required to issue and enforce patents were not wasted on ones that did not benefit the public. ${ }^{230}$ The current proposal extends this notion one step further, suggesting that the Framers would not have wanted to squander patent resources on inventions that are very likely to harm the public interest in agriculture.

A third drawback to the new utility requirement is that it might reduce investment inputs into an industry that needs all the investment it can get. Researching new technology is expensive, ${ }^{231}$ and by raising the bar to patentability, some companies might be persuaded to spend their money on other pursuits rather than face an uphill battle to get a patent. On the other hand, some commentators argue that a narrow utility requirement would benefit research by decreasing the number of research tools that are tied up by patent rights. ${ }^{232}$ Also, although patents exist to

229. Juicy Whip, Inc. v. Orange Bang, Inc., 185 F.3d 1364, 1368 (Fed. Cir. 1999) (quoting Webber v. Virginia, 103 U.S. (13 Otto) $344,347-48$ (1880)).

230. Brenner v. Manson, 383 U.S. 519,535 (1966).

231. See Philip G. Pardey et al., Creating, Protecting, and Using Crop Biotechnologies Worldwide in an Era of Intellectual Property, 6 MINN. J. L. SCl. \& TECH. 213, 215 (2004) ("In 1995 about half a trillion U.S. dollars were invested in all public and privately financed science worldwide ....").

232. See, e.g., Teresa M. Summers, The Scope of Utility in the Twenty-First Century: New Guidance for Gene-Related Patents, 91 GEO. L.J. 475, 497 (2003) ("A broad utility requirement increases privatization of basic research tools, which deepens the thicket of ownership rights and exponentially worsens transaction costs."). 
encourage inventors to invent, important goals in the safety and maintenance of our food supply should play a role in the patent process. In fact, the reduction in investment in undesirable technologies might be offset by a resulting concentration of investment in desirable technologies.

Fourth, raising the utility hurdle for agricultural inventions may dissuade some decidedly noble uses of the invention, such as the development of more nutritious rice or crops that can grow in otherwise barren, hungry nations. It must be remembered, however, that nothing is to stop these inventions from getting patents if they can meet the Criteria. If they cannot, their benefits are not worth their costs to sustainability, the environment, or public health. If they can meet the Criteria, then the new utility requirement will have placed us in a position of having our cake and eating it too.

The biggest limitation to the implementation of a new, more stringent utility requirement is its feasibility and the aforementioned problem that arose when considering that inventions can be used in more than one manner. Is it really possible to know, at the patent-granting stage, or even after the fact, how a newly developed invention will impact the sustainability, the environment, and public health? Can we really expect patent examiners to be able to determine whether a GMO will frustrate one of the Criteria when the invention might be alternatively used in a way that promotes the Criteria? Can a judge hear evidence about a technology, together with information about an environmental harm, and make a factual conclusion that the technology is responsible for the harm, and that the invention's patent should therefore be invalidated? These are difficult questions to answer.

Some guidance is found in the fact that the Federal Circuit was established in part to develop an expertise in a technical field of law, patents. ${ }^{233}$ This specialized review system might be able to wade its way through the difficult issues as the doctrine evolved. Also, each invention could be treated differently. When the consequences of the invention's implementation were too uncertain to say for sure, courts and the USPTO could err on the side of patentability. In other cases, the effects of an invention would be more certain, and the system would be able to confidently make a utility determination.

233. See generally Rochelle Cooper Dreyfuss, The Federal Circuit: A Case Study in Specialized Courts, 64 N.Y.U. L. REV. 1 (1989) (reviewing the history and jurisprudence of the Federal Circuit). 


\section{CONCLUSION}

Two constants of being human are the need to eat and the ability to invent. Throughout the course of human history, human beings have developed better and more complex ways of feeding themselves. It is this drive that led to the creation of a corn monoculture, where one plant, corn, is an integral ingredient of hundreds of food items. Our innovative instinct has most recently culminated in an accomplishment that generations before might have never imagined possible: the expression of traits of one species in an altogether different species. This feat is exciting, because it holds the potential to improve upon some of our past mistakes, but it is also worrisome, because it might lead to a whole new set of deeper, uglier mistakes. Although there may be challenges that defeat the practicality of modifying the traditional utility requirement, the legal system should consider adopting a new standard of utility that drives biotechnological innovation where we want it to go. 
